\section{PELATIHAN KOMUNIKASI POSITIF BAGI GURU SEKOLAH DASAR BERBASIS TEORI KESOPANAN BERBAHASA}

\author{
Mantasiah R. ${ }^{1}$, Hasmawati ${ }^{2}$, Yusri3 ${ }^{3}$, Muh.Anwar ${ }^{4}$ \\ Universitas Negeri Makassar ${ }^{1,2,4}$ \\ Universitas Fajar, Makassar ${ }^{3}$ \\ Email: mantasiah@unm.ac.id¹ \\ http://ojs.unm.ac.id/index.php/Insani/index
}

Abstrak. Tujuan dari penelitian ini ialah untuk mengetahui efektifitas dari modul pelatihan komunikasi positif bagi guru sekolah dasar berbasis teori kesopanan berbahasa yang telah dikembangkan. Jenis penelitian yang digunakan yakni eksperimen, dalam hal ini adalah quasi eksperimen. Partisipan dalam penelitian ini ialah 30 guru sekolah dasar yang diberikan pelatihan komunikasi positif selama 3 kali pertemuan. Teknik pengumpulan data berupa angket dengan menggunakan skala likert serta wawancara dan observasi. Teknik analisis data yang digunakan yakni statistik deskripif dan statistik inferensial dalam hal ini adalah paired sample t-test. Hasil penelitian menunjukkan bahwa terdapat peningkatan yang signifikan mengenai pemahaman guru mengenai komunikasi positif dalam proses pembelajaran. Hal tersebut membuktikan bahwa modul pelatihan yang dikembangkan effektif dalam meningkatkan pemahaman guru mengenai teknik komunikasi positif dalam proses pembelajaran.

Kata Kunci: Komunikasi Positif, Kesopanan Berbahasa, Modul Pelatihan, Gur

\section{INDONESIAN JOURNAL OF EDUCATIONAL STUDIES (IJES)}

\section{E-ISSN: 2621-6744 \\ P-ISSN: 2621-6736}

Submitted: May, $28^{\text {th }} 2019$

Accepted : June, $1^{\text {st }} 2019$

Abstract. The purpose of this study was to determine the effectiveness of the positive communication training module for elementary school teachers based on the language politeness theory that had been developed. The type of research used is experiment, in this case quasi experiment. The participants in this study were 30 elementary school teachers who were given positive communication training for 3 meetings. Data collection techniques in the form of questionnaires using Likert scale as well as interviews and observations. The data analysis technique used is descriptive statistics and inferential statistics in this case is a paired sample $t$-test. The results of the study show that there is a significant increase in teacher understanding of positive communication in the learning process. This proves that training modules are developed effectively in increasing teacher understanding of positive communication techniques in the learning process. 


\section{PENDAHULUAN}

Salah satu kemampuan yang harus ditingkatkan pada guru untuk menunjang proses pembelajaran di sekolah adalah terkait bagaimana cara guru berinteraksi dengan siswa. Beberapa hasil penelitian yang telah dilakukan oleh Rahman (2012), Shaari (2008), Murtafiah (2009) menunjukkan bahwa guru cenderung tidak memahami bagaimana harus berkomunikasi dengan siswa khususnya siswa sekolah dasar. Bahkan, berdasarkan hasil penelitian yang dilakukan oleh Mantasiah \& Yusri (2017) terdapat banyak guru yang sering menggunakan kata-kata tidak sopan dalam menegur siswa di dalam kelas, dan mereka menganggap hal tersebut adalah hal yang wajar.

Permasalahan yang serupa juga dijumpai pada guru-guru sekolah dasar di Kecamatan Mare, Kabupaten Bone, Sulawesi Selatan. Berdasarkan hasil wawancara awal yang telah dilakukan di daerah tersebut, diperoleh data bahwa 8 dari 10 guru yang diwawancarai tidak memahami bagaimana konsep ataupun cara berkomunikasi dengan siswa dengan menggunakan teori komunikasi positif, dan guru tersebut juga tidak memahami dampak apa yang ditimbulkan ketika mereka sering menggunakan kata-kata yang tidak sopan kepada siswa dalam proses pembelajaran.

Kecamatan Mare terletak di Kabupaten Bone Provinsi Sulawesi Selatan. Berdasarkan data dari UPT Pendidikan Kecamatan Mare, diperoleh informasi bahwa terdapat 28 sekolah dasar di kecamatan tersebut, sedangkan jumlah guru di sekolah dasar secara keseluruhan sebanyak 212 guru. Berdasarkan hasil wawancara dengan kepala UPT Pendidikan Kecamatan Mare, dapat disimpulkan bahwa guru sekolah dasar di kecamatan tersebut belum pernah mendapatkan pelatihan komunikasi positif dalam proses pembelajaran. Hasil wawancara dengan guru juga menunjukkan bahwa kemampuan komunikasi positif sangat dibutuhkan oleh guru dalam menunjang proses pembelajaran. Guru juga menyadari bahwa dengan kemampuan komunikasi yang baik dalam proses pembelajaran dapat berdampak positif pada motivasi akademik siswa. Namun sayangnya, mereka tidak mengimplementasikan hal tersebut dikarenakan kurangnya pemahaman mereka terkait bagaimana menggunakan komunikasi positif dalam pembelajaran

Berdasarkan latar belakang di atas, maka dipandang perlu untuk melakukan kegiatan pelatihan komunikasi positif bagi guru-guru sekolah dasar khususnya di Kecamatan Mare. Melalui pelatihan nantinya, terciptanya guru-guru yang profesional yang selalu mengimplementasikan praktek komunikasi positif dalam proses pembelajaran di sekolah. Berdasarkan permasalahan yang telah diutarakan pada bagian sebelumnya terkait rendahnya motivasi belajar siswa, perilaku bullying yang tinggi serta kemampuan guru yang kurang dalam mengelola kelas khususnya dalam aspek komunikasi positif, maka dari itu dipandang perlu untuk melakukan pelatihan komunikasi positif bagi guru untuk meningkatkan motivasi akademik siswa serta hasil belajar siswa. Hal tersebut juga nantinya akan berdampak pada menurunnya perilaku bullying pada siswa serta meningkatnya kemampuan guru dalam aspek komunikasi positif. 


\section{KOMUNIKASI POSITIF BERBASIS KESOPANAN BERBAHASA}

Komunikasi positif dalam hal ini adalah bentuk komunikasi dimana tuturan yang diucapkan sesuai dengan teori kesopanan berbahasa. Berbicara mengenai teori kesopanan berbahasa, terdapat beberapa indikator berupa maksim yang harus dipenuhi yakni maksim kebijaksanaan, maksim kedermawanan, maksim penghargaan, maksim kesederhanaan, maksim simpati, dan maksim permufakatan (Brown \& Levinson, 1978; Bowerman \& Levonson, 2001). Konsep terkait kesopanan berbahasa telah banyak dikaji dan dikembangkan oleh banyak peneliti sebelumnya seperti Blum-Kulka et al. (1985), Blum-Kulka (1987, 1990), Janney (2002), Ide (1989), Ariputra (2018), Mandala (2018), Rangkuti \& Lubi (2018), Culpeper \& Taguchi (2018) . Berdasarkan beberapa penelitian tersebut, dapat disimpulkan bahwa kesopanan berbahasa mempunyai perang penting dalam peristiwa komunikasi masyarakat, sebab terabaikannya konsep kesopanan berbahasa dalam peristiwa komunikasi dapat mengakibatkan kesalahpahaman ataupun konflik antara penutur dan mitra tutur.

Penelitian terkait kesopanan berbahasa dalam dunia pendidikan telah dikaji oleh Mantasiah \& Yusri (2017) mengenai pengaruh kesopanan berbahasa guru dalam meningkatkan motivasi akademik siswa. Hasil penelitian tersebut menunjukkan bahwa kesopanan berbahasa guru dapat meningkatkan hasil belajar dan motivasi akademik siswa di sekolah. Siswa cenderung lebih suka dengan karakter guru yang sering memuji siswa, sering memberikan penghargaan, sering memberikan perhatian dan beberapa karater lainnya yang sesuai dengan teori kesopanan berbahasa.

Berdasarkan penelitian tersebut, dapat dilihat bahwa kesopanan berbahasa juga dapat berperan dalam dunia pendidikan khususnya dalam meningkatkan motivasi belajar siswa. Berdasarkan hasil wawancara dengan beberapa siswa, dapat disimpulkan bahwa tuturan-tuturan seorang guru ataupun pendidik yang sesuai dengan teori kesopanan berbahasa dapat meningkatkan tingkat aspirasi siswa dalam kegiatan belajar. Tingkat aspirasi dalam kegiatan belajar yang dimaksud dalam hal ini mengacu pada seberapa kuat dorongan belajar siswa, terutama dalam rangka pencapaian cita-cita belajar. Hal tersebut merupakan salah satu indikator yang dapat memicu motivasi belajar siswa.

Penelitian terkait kesopanan berbahasa dengan mengaitkan disiplin ilmu lain juga telah dikaji oleh Mantasiah \& Yusri (2018) mengenai bagaimana pengaruh kesopanan berbahasa orang tua dan guru terhadap perilaku bullying siswa. Hasil penelitian menunjukkan bahwa salah satu faktor yang dapat memicu perilaku bullying siswa adalah ketidaksopanan berbahasa yang dituturkan oleh orang tua ataupun guru. Orang tua ataupun guru yang sering membentak siswa ataupun sering mengutarakan tuturan yang melanggar teori kesopanan berbahasa cenderung akan diikuti oleh siswa dan dipraktekkan dengan siswa lainnya. Hal tersebut bagian dari bullying verbal yang nantinya dapat memicu perilaku bullying fisik. Berdasarkan beberapa hasil penelitian di atas, maka dipandang bahwa pelatihan komunikasi positif berbasis teori kesopanan berbahasa sangatlah dibutuhkan oleh guru dalam menunjang proses pembelajaran yang berkualitas serta mengatasi beberapa beberapa permasalahan yang dihadapi oleh siswa seperti rendahnya motivasi akademik dan tingginya perilaku bullying di kalangan siswa. 


\section{METODE PENELITIAN}

Jenis penelitian yang digunakan yakni eksperimen, dalam hal ini adalah quasi eksperimen. Variabel dalam penelitian ini terdiri atas variable bebas yakni pemahaman guru mengenai teknik komunikasi positif berbasis kesopanan berbahasa, sedangkan variabel terikatnya adalah pelatihan komunikasi positif yang diberikan. Partisipan dalam penelitian ini ialah 30 guru sekolah dasar yang diberikan pelatihan komunikasi positif selama 3 kali pertemuan. Pelaksanaan pelatihan ini dilakukan dengan mengadopsi langkah-langkah action research yang terdiri dari 4 (empat) tahapan, yaitu: perencanaan, tindakan, observasi dan evaluasi, dan refleksi .

Teknik pengumpulan data berupa angket dengan menggunakan skala likert serta wawancara dan observasi. Sebelum mengikuti pelatihan, partisipan diberikan pre-test yang bertujuan untuk mengetahui pemahaman awal partisipan mengenai komunikasi positif. Untuk mengetahui dampak pelatihan yang telah diberikan, partisipan kembali diberikan post-test. Teknik analisis data yang digunakan yakni statistik deskripif dan statistik inferensial dalam hal ini adalah paired sample t-test. Untuk kategorisasi data pada analisis statistik deskriptif digunakan kategori dari Azwar (2004) sebagai berikut:

Tabel 1. Kategorisasi Tingkat Kesopanan Guru dalam Berkomunikasi

\begin{tabular}{cc}
\hline Interval Nilai & Kategorisasi \\
\hline$X \leq M-1,5 \sigma$ & Sangat Rendah \\
$M-1,5 \sigma<X \leq M-0,5 \sigma$ & Rendah \\
$M-0,5 \sigma<X \leq M+0,5 \sigma$ & Sedang \\
$M+0,5 \sigma<X \leq M+1,5 \sigma$ & Tinggi \\
$X>M+1,5 \sigma$ & Sangat Tinggi \\
Keterangan & \\
$M$ : Mean Hipotetik & \\
$\sigma$ : Standar Deviasi Hipotetik & \\
\hline
\end{tabular}

\section{HASIL DAN PEMBAHASAN \\ Mean dan Standar Deviasi Hipotetik}

Sebelum menyajikan data perbandingan pre-test dan post-test, terlebih dahulu disajikan nilai mean hipotetik dan standar deviasi hipotetik. Rumus yang digunakan untuk mencari mean hipotetik $(M)$ adalah sebagai berikut:

$M=1 / 2$ (i_max+i_min) $\sum k$

- i_max : Skor maksimal item (Nilai maksimal skala adalah 5)

- i_min : Skor minimal item (Nilai minimal skala adalah 1)

- $\quad \bar{k}$ : jumlah item (Jumlah item skala adalah 24)

Berdasarkan data tersebut, maka dapat dirumuskan sebagai berikut:

$M=1 / 2(5+1) 24=72$

Sedangkan, rumus yang digunakan untuk mencari standar deviasi hipotetik $(\sigma)$ adalah sebagai berikut:

$\sigma=1 / 6\left(X \_\right.$max-X_min) 
- X_max : Skor maksimal Subjek $(5 \times 24=120)$

- X_min : Skor minimal Subjek ( 1 x $24=24)$

Berdasarkan data tersebut, maka dapat dirumuskan sebagai berikut: $\sigma=1 / 6(120-24)=16$

Setelah mengetahui nilai mean dan standar deviasi hipotetik, maka dirumuskan kategorisasi tingkat kesopanan guru dalam berkomunikasi seperti pada tabel berikut:

Tabel 2. Kategorisasi Tingkat Kesopanan Guru dalam Berkomunikasi

\begin{tabular}{cc}
\hline Interval Nilai & Kategorisasi \\
\hline $\mathrm{X} \leq 48$ & Sangat Rendah \\
$48<\mathrm{X} \leq 64$ & Rendah \\
$64<\mathrm{X} \leq 80$ & Sedang \\
$80<\mathrm{X} \leq 96$ & Tinggi \\
$\mathrm{X}>96$ & Sangat Tinggi \\
\hline
\end{tabular}

Berdasarkan tabel 2, dapat dilihat bahwa terdapat 5 interval nilai mulai dari nilai kategori sangat rendah sampai nilai kategori sangat tinggi. Interval nilai ini yang digunakan untuk mengkategorikan tingkat kesopanan guru dalam proses pembelajaran.

Perbandingan Data Pre-Test dan Post-Test

Hasil analisis data terkait tingkat kesopanan guru dalam proses pembelajaran sebelum mengikuti pelatihan dapat dilihat pada table berikut:

Tabel 3. Perbandingan Data Pre-Test dan Post Test

\begin{tabular}{cccccc}
\hline Interval Nilai & Kategorisasi & \multicolumn{2}{c}{ Pre-Test } & \multicolumn{2}{c}{ Post-Test } \\
\cline { 2 - 6 } & Frekuensi & $\begin{array}{c}\text { Persentase } \\
(\%)\end{array}$ & Frekuensi & $\begin{array}{c}\text { Persentase } \\
(\%)\end{array}$ \\
\hline $\mathrm{X} \leq 48$ & $\begin{array}{c}\text { Sangat } \\
\text { Rendah }\end{array}$ & 0 & 0 & 0 & 0 \\
& Rendah & 11 & 36,67 & 3 & 10 \\
\hline $48<\mathrm{X} \leq 64$ & 17 & 56,67 & 9 & 30 \\
\hline $64<\mathrm{X} \leq 80$ & Sedang & 2 & 6,66 & 10 & 33,33 \\
\hline $80<\mathrm{X} \leq 96$ & Tinggi & 2 & 0 & 8 & 26,67 \\
\hline $\mathrm{X}>96$ & Sangat Tinggi & 0 & 100 & 30 & 100 \\
\hline \multicolumn{2}{c}{ Total } & 30 & & & \\
\hline
\end{tabular}

Berdasarkan data perbandingan nilai pre test dan post tets pada tabel 3, dapat dilihat bahwa sebelum mengikuti pelatihan, sebagian besar guru berada pada kategori sedang dengan jumlah 17 orang atau 56,67\%. Bahkan terdapat 11 guru dengan persentase $36,67 \%$ berada pada kategori rendah. Setelah mengikuti pelatihan, dapat dilihat bahwa terdapat peningkatan kesopanan guru dalam berkomunikasi. Data post-test menunjukkan bahwa sebagain besar guru yakni terdapat 10 orang atau dengan persentase 33,33\% berada pada kategori tinggi, bahkan terdapat 8 guru atau dengan persentase $26,67 \%$ berada pada kategori sangat 
tinggi. Secara umum berdasarkan data di atas, dapat disimpulkan bahwa pelatihan komunikasi positif yang diberikan berdampak pada kesadaran guru akan pentingnya memperhatikan kesopanan berbahasa dalam berkomunikasi khususnya dalam proses pembelajaran.

\section{Analisis Paired Sample T-Test}

Untuk mengetahui apakah pelatihan komunikasi positif yang diberikan kepada guru berpengaruh signifikan terhadap kesopanan berbahasa guru dalam berkomunikasi, maka dilakukan analisis paired sample t-test. Pada tabel 4 dapat dilihat hasil analisis paired sample t test dari pre-test dan post-test.

Tabel 4. Paired Samples Statistics

\begin{tabular}{lrrrr}
\hline & Mean & N & \multicolumn{1}{c}{$\begin{array}{c}\text { Std. } \\
\text { Deviation }\end{array}$} & \multicolumn{2}{c}{$\begin{array}{c}\text { Std. Error } \\
\text { Mean }\end{array}$} \\
\hline PRETEST & 70,14 & 30 & 14,061 & 2,425 \\
\hline POSTTEST & 89,63 & 30 & 11,216 & 1,871 \\
\hline
\end{tabular}

Pada tabel di atas, dapat dilihat bahwa rata-rata nilai pre test sebesar 70,14 sedangkan rata-rata nilai post-test sebesar 89,63. Maka dari itu, dapat disimpulkan bahwa terdapat peningkatan sebesar 19,49. Untuk lebih jelasnya terkait peningkatan tersebut, dapat dilihat pada tabel berikut:

Tabel 5 Paired Sample T-Test

\begin{tabular}{|c|c|c|c|c|c|c|c|c|}
\hline & \multicolumn{5}{|c|}{ Paired Differences } & \multirow[t]{3}{*}{$\mathrm{T}$} & \multirow[t]{3}{*}{$d f$} & \multirow{3}{*}{$\begin{array}{c}\text { Sig. } \\
(2- \\
\text { tailed })\end{array}$} \\
\hline & \multirow[t]{2}{*}{$\begin{array}{c}\text { Mea } \\
\mathrm{n}\end{array}$} & \multirow[t]{2}{*}{$\begin{array}{l}\text { Std. } \\
\text { Deviat } \\
\text { ion }\end{array}$} & \multirow[t]{2}{*}{$\begin{array}{l}\text { Std. } \\
\text { Error } \\
\text { Mean }\end{array}$} & \multicolumn{2}{|c|}{$\begin{array}{c}95 \% \\
\text { Confidence } \\
\text { Interval of } \\
\text { the } \\
\text { Difference }\end{array}$} & & & \\
\hline & & & & $\begin{array}{c}\text { Low } \\
\text { er }\end{array}$ & $\begin{array}{c}\text { Upp } \\
\text { er }\end{array}$ & & & \\
\hline POSTTEST & 19,4 & 11,216 & 1,871 & 38,2 & 98,11 & 11,51 & 31 & ,000 \\
\hline - PRETEST & 9 & & & 81 & 4 & 4 & & \\
\hline
\end{tabular}

Berdasarkan data pada tabel 5, dapat dilihat bahwa nilai signifikansi sebesar 0,000, maka dapat disimpulkan bahwa terdapat peningkatan yang signifikan terkait kesopanan guru dalam berkomunikasi setelah mengikuti pelatihan. Peningkatan kesopanan berbahasa dalam hal ini terjadi disebabkan guru mulai menyadari pentingnya kesopanan berbahasa ketika berkomunikasi dengan siswa dalam proses pembelajaran. Selain itu guru juga telah memahami bahwa penggunaan bahasa yang mereka gunakan dalam proses pembelajaran akan berdampak pada motivasi dan hasil belajar siswa. Pemahaman tersebut tentunya diperoleh pada saat pelatihan komunikasi positif. Berdasarkan data tersebut, maka disarankan agar kiranya pelatihan-pelatihan yang mengarah pada peningkatan kemampuan guru dalam 
berkomunikasi dengan siswa juga dapat diterapkan secara luas, sehinga nantinya akan berdampak positif pada peningkatan kualitas pembelajaran.

\section{KESIMPULAN}

Pelatihan komunikasi positif berbasis teori kesopanan berbahasa dapat meningkatkan pemahaman guru terkait kesopanan berbahasa dalam proses pembelajaran. Guru telah dapat membedakan yang mana tuturan yang sopan dan yang mana tuturan yang tidak sopan untuk diutarakan kepada siswa dalam proses pembelajaran.

\section{DAFTAR PUSTAKA}

Rahman, K. A. A. (2012). Disposisi Guru Berkesan: Personaliti dan Kemahiran Komunikasi (Effective Teacher Dispositions: Personality Traits and Communication Skills). Akademika, 82(2).

Shaari, A. S. (2008). Guru berkesan petua dan panduan. Penerbit Universiti Utara Malaysia.

Murtafiah, N. (2009). Pengaruh Kemampuan Komunikasi Guru Dalam Proses Belajar Mengajar Terhadap Kepuasan Belajar Pelajaran Akuntansi Kelas XI IPS Di SMA $N 6$ Semarang (Doctoral dissertation, Universitas Negeri Semarang).

Culpeper, J., Mackey, A., \& Taguchi, N. (2018). Second Language Pragmatics: From Theory to Research. Routledge.

Rangkuti, R., \& Lubis, A. P. (2018, April). PROBLEMS IN MULTICULTURAL SOCIETY: FROM LANGUAGE POLITENESS TO HATE SPEECH. In AICLL: ANNUAL INTERNATIONAL CONFERENCE ON LANGUAGE AND LITERATURE (Vol. 1, No. 1, pp. 255-261).

Ariputra, A. M., Rohmadi, M., \& Sumarwati, S. (2018). LANGUAGE POLITENESS PRINCIPLE IN INDONESIA LAWYERS CLUB TALKSHOW ON TV ONE. OKARA: Jurnal Bahasa dan Sastra, 12(1), 115-124.

Brown, P. dan Levinson, S. 1987. Politeness: Some Universals in Language Usage.

Bowerman, M., Levinson, S. C., \& Levinson, S. (Eds.). (2001). Language acquisition and conceptual development (No. 3). Cambridge University Press.

Blum-Kulka, S., House, J., \& Kasper, G. (1989). Cross-cultural pragmatics: Requests and apologies (Vol. 31). Ablex Pub.

Mandala, H. (2018). Divergent Principles of Politeness in Verbal and Non-Verbal Directive Speech Act. International Research Journal of Engineering, IT and Scientific Research (IRJEIS), 4(2), 41-51.

Mantasiah, M., \& Yusri, Y. (2017, August). The Influence of Teacher's Language Politeness in Improving Student's Academic Motivation. In 8th International Conference of Asian Association of Indigenous and Cultural Psychology (ICAAIP 2017). Atlantis Press.

Blum-Kulka, S., Danet, B., \& Gherson, R. (1985). The language of requesting in Israeli society. In Language and social situations (pp. 113-139). Springer, New York, NY.

Blum-Kulka, S. (1987). Indirectness and politeness in requests: Same or different?. Journal of pragmatics, 11(2), 131-146. 
Janney, R. W. (2002). Cotext as context: Vague answers in court. Language \& Communication, 22(4), 457-475.

Ide, S. (1989). Formal forms and discernment: Two neglected aspects of universals of linguistic politeness. Multilingua-journal of cross-cultural and interlanguage communication, 8(2-3), 223-248. 